Gut, 1983, 24, 161-164

\title{
Serum isoamylase as a test for pancreatic insufficiency
}

\author{
S M NASRALLAH* AND D M MARTIN
}

From the University of Maryland, Baltimore, Maryland, and Department of Medicine, Emory University
School of Medicine. Atlanta, Georgia, USA

SUMmaRY Total and pancreatic serum isoamylases were performed on 38 control subjects (21 non-smokers and 17 smokers) and 21 consecutive patients with pancreatic insufficiency before and after meal stimulation. There was no difference in the fasting or stimulated levels of total amylase $(\mathrm{T})$, pancreatic isoamylase $(\mathrm{P})$, or \% $\mathrm{P} / \mathrm{T}$ between smokers and non-smokers. The $\mathrm{P} / \mathrm{T}$ ratio was significantly reduced in patients with pancreatic insufficiency when compared with each of the control groups $(\mathrm{p}<0.0005)$. Eleven of 21 patients with pancreatic insufficiency had raised total serum amylase, but none had a rise in the pancreatic fraction or $\mathrm{P} / \mathrm{T}$ ratio. Our findings indicate that the $\mathrm{T}, \mathrm{P}$, and $\mathrm{P} / \mathrm{T}$ ratio of serum amylase are not influenced by smoking or meal stimulation. A reduced $\mathrm{P} / \mathrm{T}$ ratio in a patient with steatorrhoea suggests pancreatic insufficiency as the cause. Hyperamylasaemia in patients with pancreatic insufficiency does not necessarily imply a relapse.

Several tissues contribute to the serum level of amylase. but the major components are the salivary $(S)$ and pancreatic (P) fractions. Determination of amylase isoenzyme may indicate the origin of circulating amylase. The specificity of raised pancreatic isoamylase in the diagnosis of acute pancreatitis, and in its differentiation from other causes of abdominal pain. has been previously described. ${ }^{12}$ In this setting, a ratio of pancreaticto-total $(\mathrm{P} / \mathrm{T})$ amylase of greater than $80 \%$ is presumptive evidence of acute pancreatitis. ${ }^{3}$ Pancreatic isoamylase has also been reported to be raised in cigarette smokers compared with nonsmokers. ${ }^{+}$In contrast. sporadic reports from Europe have found low levels of pancreatic isoamylase in patients with chronic pancreatitis. ${ }^{56}$.

The routine use of isoamylase measurements as a clinical diagnostic tool has been hindered by the cumbersome and time-consuming methodology required: isoelectric focusing. ${ }^{7}$ electrophoresis, ${ }^{8}$ or chromatography. ${ }^{9}$ The recent development of a rapid technique using an inhibitor of the salivary isoamylase fraction ${ }^{10}$ has simplified this measurement. and made the test suitable for routine use in the clinical laboratory.

\footnotetext{
* Address for correspondence: Dr Salah M. Nasrallah. University of Maryland. GI Division - Room N3W148. 22 South Greene Street. Baltimore. Maryland 21201. USA.

Received for publication 3 June 1982
}

The purpose of this report is to: (1) describe the reproducibility of this technique; (2) determine isoamylase levels in a normal population of nonsmokers and smokers; (3) evaluate the usefulness of pancreatic isoamylase as a test for pancreatic insufficiency; and (4) assess the effect of meal stimulation on serum isoamylase levels.

\section{Methods}

PATIENTS

This study was approved by the Human Investigations Committee of the Emory University School of Medicine.

Thirty-eight volunteers, 21 non-smokers and 17 smokers, and 21 consecutive patients with pancreatic insufficiency attending the Pancreatic Clinic were investigated. The control population included medical personnel, medical students, and laboratory technicians who were not regular users of ethanol. Smokers used at least 10 cigarettes daily.

Pancreatic insufficiency was diagnosed on the basis of either steatorrhoea or an abnormal phenylacetic oil test, ${ }^{11}$ in addition to at least one of the following: pancreatic calcifications, beaded pancreatic duct on ERCP ('chain of lakes'), decreased bicarbonate secretion on secretin test, or documentation of chronic pancreatitis at surgical exploration. In all cases, pancreatic insufficiency was the result of chronic relapsing (alcoholic) 
pancreatitis. At the time of testing, patients were pain free and had abstained from drinking for at least four weeks.

\section{TESTING PROCEDURE}

After a fasting venous blood sample was obtained, patients ate a test meal consisting of a ham sandwich, potato chips, a carbonated beverage, or coffee. A second blood sample was obtained 30 minutes after the meal. The serum was separated, and stored frozen at $-20^{\circ} \mathrm{C}$ until the time of analysis.

\section{ISOAMYLASE DETERMINATION}

Measurement of total serum amylase was performed by the Phadebas method. ${ }^{12}$ The pancreatic or non-salivary isoamylase fraction was measured after the addition of a wheat protein, Triticum aestivum, which is 100 -fold more potent an inhibitor of salivary than pancreatic isoamylase. Serum blanks and reference control sera were inclued with each run of patient sera, and a standard P/S curve generated for each run. As a test of reproducibility, we performed the first 20 determinations in duplicate. For an additional three control subjects, the test was performed repeatedly using the same serum sample on at least five separate occasions.

The $\mathrm{P} / \mathrm{S}$ ratio in patient sera was determined from the generated $\mathrm{P} / \mathrm{S}$ curve. The $\mathrm{P} / \mathrm{T}$ ratio was calculated using the following formula:

$$
\mathrm{P}=\frac{\mathrm{T} \times \mathrm{P} / \mathrm{S}}{1+\mathrm{P} / \mathrm{S}} \text { or } \% \mathrm{P} / \mathrm{T}=\frac{\mathrm{P} / \mathrm{S}}{1+\mathrm{P} / \mathrm{S}} \times 100
$$

The normal values for total amylase were taken as less than $300 \mathrm{U} / \mathrm{l}$, and for pancreatic isoamylase less than $198 \mathrm{U} / 1$.

Because of the shape of the P/S curve, quantitative determinations of $\mathrm{P} / \mathrm{T}$ could be made only within the range of $9.1 \%$ to $88.9 \%$, respectively.
STATISTICAL ANALYSIS

All results are expressed as mean \pm SEM. Significance levels were determined using Student's $t$ test for comparison of the means.

The reproducibility of measuring total and pancreatic isoamylase fractions agreed within $10 \%$ in both the duplicate samples and in samples measured repeatedly on different occasions. There was no significant variation in the shape or position of the standard P/S curve generated with each run.

The results of the total amylase, pancreatic isoamylase, and $\mathrm{P} / \mathrm{S}$ ratio before and after meal stimulation are presented in the Table. The pancreatic fraction was approximately $50 \%$ of the total amylase in both control groups. There were no differences between smokers and non-smokers for any of the values measured. Meal stimulation did not result in a significant change in either $\mathrm{T}, \mathrm{P}$, or $\mathrm{P} / \mathrm{T}$ levels (Figure).

Eleven of 21 patients with pancreatic insufficiency had raised total serum amylase (range, 149-972 $\mathrm{U} / \mathrm{l})$, but none had a raised pancreatic isoamylase level (range 15-168 U/l). None of these patients had clinical evidence of parotitis but two had slightly enlarged glands. Significant differences between patients with pancreatic insufficiency and both control groups were seen for values of $\mathrm{T}, \mathrm{P}$, and $\mathrm{P} / \mathrm{T}$ ratio (Table). In particular, the $\mathrm{P} / \mathrm{T}$ ratio distinguished the pancreatic insufficiency group from controls, $\mathrm{p}<0.0005$ (Figure). Using a $\mathrm{P} / \mathrm{T}$ ratio of $30 \%$ as the dividing line between pancreatic insufficiency and controls, the rate of false positives among controls was $10.5 \%$, and the rate of false negatives in pancreatic insufficiency $19 \%$.

\section{Discussion}

The recent recognition that a component of wheat protein inhibits the activity of salivary amylase ${ }^{10}$ has led to its use in the measurement of the pancreatic

Table Serum values of total amylase $(T)$, pancreatic isoamylase $(P)$, and \% P/T ratio in non-smokers, smokers, and patients with pancreatic insufficiency, before and 30 minutes after meal stimulation

\begin{tabular}{|c|c|c|c|c|c|c|}
\hline & \multicolumn{2}{|c|}{$\begin{array}{l}\text { Total Amylase } \\
(U / l)\end{array}$} & \multicolumn{2}{|c|}{$\begin{array}{l}\text { P-isoamylase } \\
\text { (UIl) }\end{array}$} & \multicolumn{2}{|l|}{$\% P / T$} \\
\hline & Fasting & After & Fasting & After & Before & After \\
\hline Non-smokers & $234 \pm 15$ & $242 \pm 19$ & $106 \pm 7$ & $118 \pm 11$ & $48 \pm 3$ & $52 \pm 3$ \\
\hline Smokers & $222 \pm 21$ & $221 \pm 20$ & $108 \pm 8$ & $105 \pm 8^{+}$ & $51 \pm 4$ & $49 \pm 3$ \\
\hline Pancreatic insufficiency & $383 \pm 47$ & $438 \pm 63$ & $74 \pm 10$ & $78 \pm 11$ & $23 \pm 4$ & $21 \pm 4$ \\
\hline Values of $p^{*}$ & $<0.01$ & $<0 \cdot 01$ & $<0.02$ & $<0.02$ & $<0.0005$ & $<0.0005$ \\
\hline
\end{tabular}

Results are means \pm SEM

* $p$ values indicate level of significance between pancreatic insufficiency and each of two control groups.

$+\mathrm{p}$ not significant $v s$ pancreatic insufficiency. 


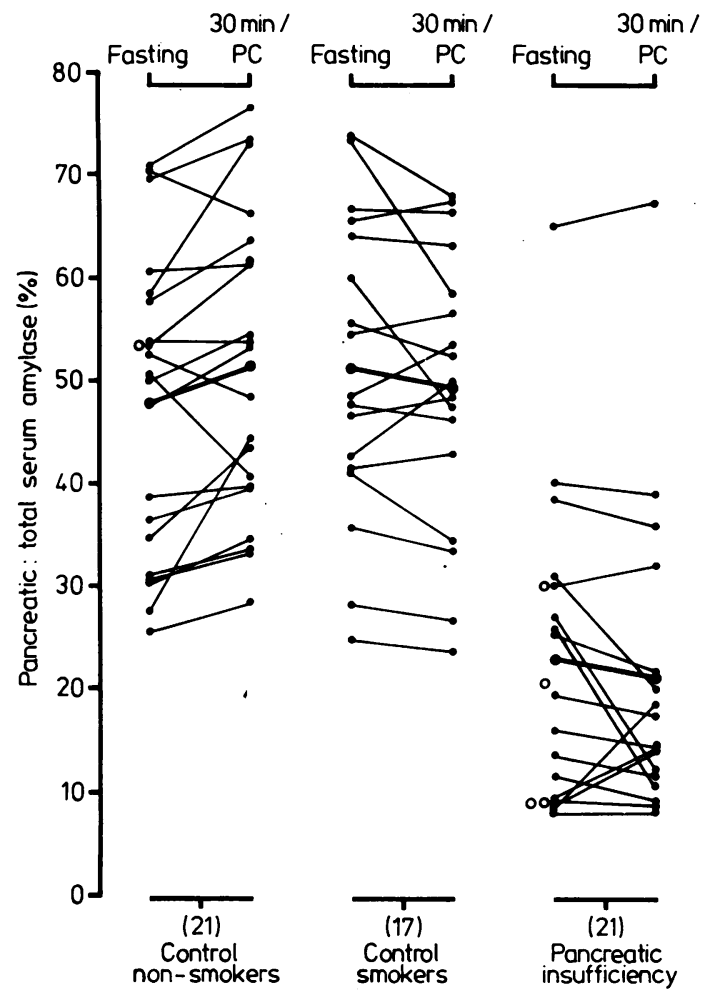

Figure Comparison of $\% P / T$ ratio in fasting state and 30 minutes after a test meal (PC) in non-smokers, smokers, and patients with pancreatic insufficiency. $\circ$ Fasting values in subjects without meal stimulation. - Mean for each group.

and salivary fractions of amylase. Our results, like those of Levitt et al,${ }^{13}$ indicate that the quantitative measurement of isoamylases using this method is simple, accurate, and reproducible. We found less than $10 \%$ variation in repeated determinations on the same sera, and in determinations on duplicate sera. Levitt et al ${ }^{13}$ have previously shown a good correlation between this method for isoamylase assay and isoelectric focusing $(r=0 \cdot 89)$.

As shown in the Table, there was a significantly lower ratio of $\mathrm{P} / \mathrm{T}$ in the sera of patients with pancreatic insufficiency when compared with those of normal control subjects $(p<0 \cdot 0005)$. This difference reflects a relatively low output of pancreatic amylase, as pancreatic insufficiency is associated with over $90 \%$ reduction in pancreatic function. Another possible explanation for this finding is an increased renal clearance of pancreatic but not salivary, isoamylase in patients with chronic pancreatitis as suggested by Hegarty et al. ${ }^{15}$ This, however, cannot be the main explanation as Magid et at found normal p-isoamylase levels in most patients with mild to moderate reduction of pancreatic function. This latter observation and our finding of reduced $\mathrm{P} / \mathrm{T}$ ratio in over $80 \%$ of patients with pancreatic insufficiency, favour the utility of this ratio as a screening test for pancreatic insufficiency. As the pancreatic insufficiency encountered in all of our patients was the result of alcohol abuse, our findings cannot be projected to other causes of pancreatic insufficiency. Although others have observed low levels of p-isoamylase in pancreatic insufficiency ${ }^{5} 616$ this finding did not gain clinical application because of the complex methodology required. In contrast, this isoamylase assay ${ }^{10}$ requires only a little more additional time than the standard amylase test.

Our data also show that neither meal stimulation nor chronic cigarette smoking influence the serum pattern of amylase isoenzymes. These observations are at variance with those of Balldin et al ${ }^{4}$ who found raised pancreatic isoamylase levels in smokers both before and after secretin stimulation. The reason for this discrepancy is not clear.

Over $50 \%$ of our patients with pancreatic insufficiency had raised levels of total serum amylase, yet none had rises in the pancreatic fraction. This observation is of clinical significance, as it casts doubt on the value of routine total amylase determination as a measure of disease relapse in this group of patients. Measurement of pancreatic isoamylase would be a more accurate index of the disease activity. Our results cannot be compared with those of Dutta et $\mathbf{l}^{17}$ who evaluated amylase level in acute alcoholics, as all of our patients have abstained from drinking for at least three months before testing.

We conclude that the isoamylase test is reproducible, easy to perform, and not affected by meal stimulation or smoking. Hyperamylasaemia of non-pancreatic origin is seen frequently in patients with pancreatic insufficiency.

The authors wish to acknowledge the able technical assistance of Mrs Sandra J Wagner. (The Phadebas IsoAmylase Test kit was generously given by $\mathrm{Dr}$ Gary Britton, Pharmacia Diagnostics).

\section{References}

1 Warshaw AL, Lee $\mathrm{K}-\mathrm{H}$. The mechanism of increased renal clearance of amylase in acute pancreatitis. Gastroenterology 1976; 71: 388-91.

2 Long WB, Grider JR. Amylase isoenzyme clearances in normal subjects and in patients with acute 
pancreatitis. Gastroenterology 1976; 71: 589-93.

3 Levitt MD, Ellis C. Serum isoamylase measurements in pancreatitis complicating chronic renal failure. $J$ Clin Med 1979; 93: 71-8.

4 Balldin G, Borgström A, Eddeland A, Genell S, Hagberg L, Ohlsson K. Elevated serum levels of pancreatic secretory proteins in cigarette smokers after secretin stimulation. J Clin Invest 1980; 66: 150-62.

5 Aw SE, Hobbs JR, Wootton IDP. Urinary isoamylases in the diagnosis of chronic pancreatitis. Gut 1967; 8: 402-7.

6 Magid E, Horsing M, Rune SJ. On the quantitation of isoamylases in serum and the diagnostic value of serum pancreatic type amylase in chronic pancreatitis. Scand J Gastroenterol 1977; 12: 621-7.

7 Levitt MD, Ellis C, Engel RR. Isoelectric focusing studies of human serum and tissue isoamylases $J \mathrm{Lab}$ Clin Med 1977; 90: 141-52.

8 Skude G. Electrophoretic separation, detection and variation of amylase isoenzymes. Scand J Clin Lab Invest 1975; 35: 41-7.

9 Fridhandler L, Berk JE, Ureda M. Isolation and measurement of pancreatic amylase in human serum and urine. Clin Chem 1972; 18: 1493-7.

10 O'Donnell M, Fitzgerald O, McGreeney KF. Differential serum amylase determination by use of an inhibitor, and design of a routine procedure. Clin Chem 1977; 23: 56()-6.

11 Nasrallah SM, Al-Khalidi UAS. Clinical value of ${ }^{14} \mathrm{C}$-phenyl-acetic oil as a fat absorption test. Lancet 1980; 1: 229-31

12 Ceska M, Birath K, Brown B. A new rapid method for the clinical determination of $\alpha$-amylase activities in serum and urine, optimal conditions. Clin Chim Acta 1969; 26: 437-44.

13 Levitt MD, Ellis C, Koehler DF, Eckfeldt JH. Use of a salivary isoamylase inhibitor for isoamylase assay. (Abstract) Nat Pancreat Cancer Project Newsl 1980; 5: 6.

14 DiMango EP, Go VLW, Summerskill WHJ. Relations between pancreatic enzyme outputs and malabsorption in severe pancreatitic insufficiency. $N$ Engl J Med 1973; 288: 813-5.

15 Hegarty JE, O'Donnell MD, McGeeney KF, Fitzgerald $O$. Pancreatic and salivary amylase/ creatinine clearance pancreatitis. Gut 1978; 19: 350-4.

16 Johnson SG, Levitt MD. Relation between serum pancreatic isoamylase concentration and pancreatic exocrine function. Dig Dis 1978; 23: 914-8.

17 Dutta SK, Douglass W, Smalls UA, Nipper HC, Levitt MD. Prevalence and nature of hyperamylasemia in acute alcoholism. Dig Dis Sci 1981; 26: 136-41. 